\title{
Accessibility for Physically Challenged Persons in Heritage Buildings
}

\author{
Phan Meng Hooi ${ }^{1 *}$, Naziaty Mohd Yaacob ${ }^{1}$ \\ ${ }^{I}$ Faculty of Built Environment, University of Malaya, 50603 Kuala Lumpur, Malaysia. \\ *mengphan@gmail.com
}

Received : 4 February 2017 Final Version Received: 16 April 2019

Enforcement of amendment to the Uniform Building By-Law in Section 34A and Persons with Disability Act 2008 has elevated accessibility needs for physically challenged persons to mainstream development in Malaysia especially tourism industry. It is parallel to regional resolution and convention reiterating accessible tourism in the industry whilst achieve 'Inclusive, barrier free and right based' society. Accessibility has been further intensified within heritage buildings to benchmark high quality of tourism industry and importantly promotes social equality. In fact heritage tourism has been another gateway to elaborate fundamental accessibility needs of persons with disabilities in all aspects. Legislative framework has yet encapsulated both approaches comprehensively especially deficiency in provision of statutory requirements. There is lack of supportive guideline to address gaps between National Heritage Act and Persons with Disabilities Act. In this regards, current practice has shown professionals and consultants not well comprehend to weight balance between conservation principle and barrier free environment approach in restoring heritage buildings. However, the importance of accessibility needs is notably shown in the case studies to engage social inclusion in current practice. Access auditing reported the selected heritage sites including St. George Church, Leong San Tong Khoo Kongsi and Suffolk House have potential to include the accessibility needs without diminishing its heritage significance. As long access strategy and accessible mapping are identified during the initial stage to connect the core elements depending on its unique original fabric. Certainly never a fixed standard appending to current building regulations is applicable to all heritage sites. The research concluded barrier free environment approach is possible to reconcile with conservation principle within reasonable accommodation from case to cases basis.

Keywords: Cultural Tourism, Accessible Tourism, Accessibility, Accessible Heritage, Conservation

\section{INTRODUCTION}

Demographic trend indicates increasing population of persons with disabilities (PwDs) over the year from 313,685 persons (2010) to 506,228 persons (2014) in Malaysia (Department of PwDs, Malaysia); hence Department of Social Welfare (2014) reported voluntary registered PwDs stands only $1.7 \%$ of population in Malaysia. While World Report to Disability (2011) estimated about 5\% of total population of a country is the true percentage as registration in voluntary. The statistic draws out awareness on there are substantial underserved group in the mainstream development and their human rights are often eliminated. Up till the United Nation of Convention on the Rights of Persons with Disabilities (CRPD) has enlightened full participation and inclusion of PwDs in society. It recognizes importance of accessibility to physical, social, economic and cultural environment; to health and education and to information and communication, in enabling PwDs to fully enjoy human rights and fundamental freedom (CRPD, 2006). Although the United Nation Declaration of Human Rights upheld human rights of PwDs in 1948 yet has not been translated into action during the decade. The attempt became significant only after recognition importance of inclusive travel officially by World Tourism Organization (WTO) in 1985 and provision of accessibility needs has been included in tourism sector since the ratification of Declaration on the Rights of 
Persons with Disabilities in 2007 by United Nation.

Moving forwards, there are series of Declaration of Accessible Tourism in Asia Pacific has driven development of accessible tourism besides the three major regional instruments; including the CRPD, Biwako Millennium Framework for Action (BMF) and BMF Plus Five. The accessible tourism has been reaffirmed under commitment of WTO in 1999; within its Article 2 and Article 7 of 'Global Code of Ethnics for Tourism' (Van Horn, 2006: WTO, 2011). While CRPD proclaims human rights specifically in Article 9 (Access to information, service, transportation and facilities) and Article 30 (Participation in cultural life, recreation, leisure and sports). Apparently, it recognizes importance of accessibility in cultural environment to ensure their human rights in full participation. Nevertheless, accessible heritage is still a new phenomenon in Asia and Pacific and under-researched matter in the cultural tourism industry.

Departing from the international conventions and proclamations, accessibility needs has been decisively reiterated in achieving barrier free, inclusive and right based society. Overview to previous researches, Darcy(1998), Van Horn (2006) and Butan (2011) concluded tourism is the right base to takeoff the inception of accessibility needs for physically challenge persons. They even strengthened tourism is a living example of how much a person can fully and effectively enjoy human rights and fundamental freedoms as stated in all human rights instruments. To certain extent, tourism is a social based industry constituted by basic principle of social interaction between service providers and end users. It includes concepts of converging and balancing guidance between responsibility, ethically industry and consumer industry. Besides, overviewing the macro perspectives on tourism industry; accessible heritage has well developed and became global aspiration especially in developed countries. In such, the paper attempts to explore the barrier free environment approach in addressing accessibility needs for physically challenge persons within heritage buildings in Malaysia.

The paper begins by understanding the concept in incorporating barrier free environment approach with conservation principle within heritage buildings in Malaysia context. This is followed by studying current legislative framework in accommodating the needs. In light of the literature review, the paper examines provisions of the accessibility needs within heritage properties in current phenomenon. Next, the paper tends to discover the design principle to reconcile both conservation principle and barrier free environment approach to achieve accessible heritage. For the purpose of this paper, the term persons with disabilities (PwDs) specifically refers to physically challenged persons; whom the end users with physical disabilities on limited mobility including wheelchair users and clutches users.

\section{RESEARCH METHODOLOGY}

The research subject encompasses two major supported studies which are heritage conservation and accessibility for PwDs. The research focuses whether accessibility needs of PwDs are accommodated within heritage buildings in this phenomenal research. The know-how reconciliation both conservation principles and barrier free environment design approaches are highly accentuated. With focus of both subject areas concurrently, 'conservation' and 'accessibility' were the key words and title in search. The term 'barrier free environment' was employed to research the related secondary literature in various types of publication, previous research papers and articles.

In view of the research area is a fairly new inception to Asia Pacific especially Malaysia since enforcement of Persons with Disability Act in 2008 and National Heritage Act in 2005. The phenomenon and context are yet clearly distinguishable in real-life situation. Limited literature had been found in current research base. Thus exploratory case study was centered as research strategy to explore access provision within heritage buildings in Malaysia. The direct observation was conducted with 'access auditing' protocol to the selected heritage buildings. The access auditing checklist which was previously employed by Yaacob \& Hashim (2000); was the basis of observation tool in assessing provision of accessibility on sites. The checklist was derived from the Malaysia Standard 1184:2002 - Code of Practice on Access for Disabled Persons to Public Buildings and the UNESCAP recommendations (Yaacob \& Hashim, 2008). The checklist monitored the access auditing to identify appropriateness of access provision in current practice.

Prior to the case study, legislative framework of conservation and disability movement was undertaken in the secondary data review. The process outlined development of both areas to 
what extent coalition in conservation principle with barrier free environment approach within heritage conservation. It indicated design framework being practiced by local service providers and managing owners of heritage property in Malaysia.

Since George Town has been inscribed as UNESCO World Heritage Sites, case studies in the area exemplify implementation of legislation framework and action plan in conservation practice. The cases impinge upon the ideology of conservation framework which is restrained within the local enactment 'Guidelines for
Conservation Areas and Heritage Building in George Town' and National Heritage Act. Thus the case study well reflects implication of barrier free approach within conservation practice in view of statutory framework and service providers' input. To certain extend, the sampling units for three heritage building are also pinned down within inclusion;

a. Awarded conserved buildings which performed high quality in conservation principle

b. Restoration sought to be undergone within 10 years upon enforcement of the UBBL Section 34A in compliance with requirement provision for PwDs

Table 1: Three selected case studies in George Town

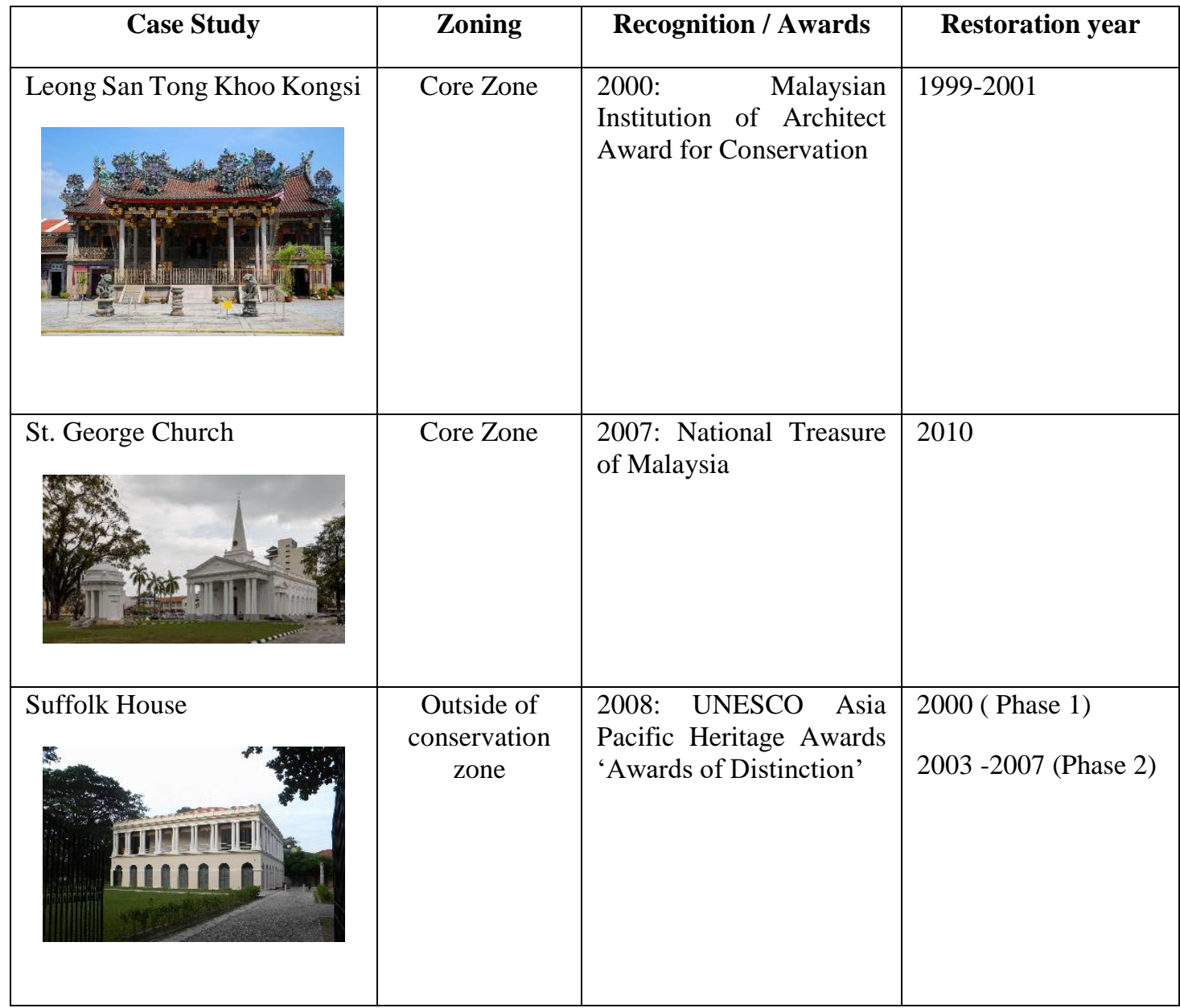

\section{LEGISLATIVE FRAMEWORK}

Disability movement was significant in Malaysia since enforcement of Persons with Disability Act on $7^{\text {th }}$ July 2008 when Malaysia became signatory of the Proclamation of Full Participation and Equal Opportunities of PwDs in Asia Pacific in 1994. It evidently notes human right of PwDs has been incepted into mainstream development in Malaysia since then. The Act recognizes that disability is an evolving concept and results from interaction of PwDs and attitudinal and environmental barriers that hinders their full and effective participation in 
society on an equal basis with persons without disabilities. In other words, attitudinal and environmental barriers are the major factors of inaccessibility for PwDs. By removing the physical obstacles and social barriers which was affirmed by UNESCAP would achieve barrier free environment. The environmental barriers approach refers to physical amenities or facilities in place which shall fit to accessibility and usability for PwDs, including safety of PwDs during design stagey. Herein the accessibility, usability and safety which are the fundamental aspects of barrier free environmental concept as claimed by Yaacob, N.M., Hashim, N.R. \& Aman Hashim, H. (2009), are the recognized physical barriers in Persons with Disabilities Act 2008 (Act 685).

To further extent, the barrier free environment concept was adopted in Takayam Declaration which promoting accessible tourism also entails removal of attitudinal and institutional barriers in society, and encompasses accessibility in physical environment (ENAT, 2009). It is parallel with the Persons with Disabilities Act which further claims the importance of accessibility to the physical, social, economic and cultural environment, to health and education and to information and communication, in enabling PwDs to fully and effectively participate in society (Persons with Disability Act 2008, Act 685). Looking closely, it specifically mentions cultural environment should make accessible as stated in Article 31;

'Access to cultural life

31(2) Persons with disabilities shall have the right to enjoy access -

(c) to place for cultural performances or services such as theaters, museum, cinemas, libraries and tourism services, and as far as possible, to monuments and sites of national cultural importance.

(Persons with Disabilities Act, 2008)

The Article clearly admits rights of PwDs to access heritage sites and involves in cultural tourism without discrimination. Indeed, it is mandatory to the provision since Malaysia joints the Declaration on the Global Code of Ethics for Tourism in 2014 which has been adopted by WTO General Assembly in 1999. Whereby the Article 2 (Tourism as a vehicle for individual and collective fulfillment) and Article 7 (Right to tourism) also mention the inclusion of accessibility for PwDs in tourism segment. Thus accessibility needs for PwDs shall be accommodated in tourist spots including heritage sites especially the recognized UNESCO World Heritage status in the Malacca and George Town, historic cities of the Straits of Malacca in Malaysia.

Emergence of the Persons with Disabilities Act 2008 also came resultant to amendment to Uniform Building By-Laws (UBBL) introduces Section $34 \mathrm{~A}$ to specify all new public and existing buildings which were built before enforcement date on 13 August 1993 to provide access into, out of and within the buildings. The amended UBBL Section 34A makes mandatory for all public buildings new built, or have been erected, approved plan shall be modified or altered to comply with this by-law within three years from the commencement date. However the provision is binding on all state governments but the gazette year depends on each state as shown in Table 2. It evidently shows implementation and enforcement of both Persons with Disabilities Act and UBBL34A are still lax (Hussein, H. \& Yaacob, N.M., 2012, 2013).

Table 2: Gazatted dates of UBBL 34A in respective states in Malaysia

\begin{tabular}{|c|c|c|c|}
\hline \multicolumn{4}{|c|}{$\begin{array}{l}\text { LIST OF STATE GAZETTE NOTIFICATION ON AMENDMENT TO UBBL } 1984 \text { ON BUILDING } \\
\text { REQUIREMENTS FOR DISABLED PERSONS }\end{array}$} \\
\hline $\mathrm{NO}$ & STATE & GAZETTE DATE & GAZETTE DOCUMENT \\
\hline 1 & Perlis & 3 March 1994 & PS.P.U.2 \\
\hline 2 & Kedah & 30 November 1992 & - \\
\hline 3 & Pulau Pinang & 11 November 1993 & Pg..P.U.26 \\
\hline 4 & Perak & 13 May 1994 & Pk.P.U.26 \\
\hline 5 & Selangor & 20 January 1994 & Sel.C.U.95 \\
\hline 6 & Negeri Sembilan & 31 January 1991 & N.S.P.U.1 \\
\hline 7 & Melaka & 22 May 1996 & - \\
\hline 8 & Johor & 7 May 1992 & J.P.U.14 \\
\hline 9 & Pahang & 28 March 1996 & - \\
\hline 10 & Terengganu & 15 December 1993 & - \\
\hline 11 & Kelantan & 3 July 1992 & Kn.P.5/92 \\
\hline 12 & Wilayah Persekutuan & 13 August 1993 & P.U.A.305/92 \\
\hline
\end{tabular}


The requirement of the UBBL34A shall be deemed to comply with Malaysia Standards:

1. SIRIM Code of Practice MS 1184:2014Coder of Practice on Access for Disabled Persons to Public Buildings

2. $\quad$ SIRIM Code of Practice MS 1331: 2003 - Code of Practice for Access of Disabled Persons Outside Buildings (First Revision)

3. SIRIM Code of Practice MS 1183: Part 8:1990 (P) - Specification for Fire Precautions in the Design and Construction of Buildings Part 8: Code of Practice for Means of Escape for Disabled People

The MS1184:2014 and MS 1183: Part 8:1990 (P) include the cultural and entertainment use buildings to fit the requirements. Especially the design of escape routes and the organization of management procedures are particularly critical in these classes of buildings because the users are likely to be unfamiliar with their surroundings and population densities in terms of the number of persons per unit area are very high (MS 1183: Part 8:1990 (P)). The Malaysia Standard well informs the importance of safety aspect for PwDs in entertainment and cultural use buildings. In this case, existing heritage buildings especially public access tourism sites shall be included in the enforcement.

In contrast, there is no specific article disclose accessibility within heritage properties in National Heritage Act 2005. The Act focuses on conservation aspects but lack of supportive design standards or codes of practices in building heritage. The Act is only applicable to selective heritage buildings which are listed under criteria and collectible sampling. Besides, there are different enactments based on general principles, interpretations and implications depending on respective traits; for example 'Design Guideline for the Conservation Zones in the Inner City of Georgetown in Penang whereas Enactment on Conservation and Restoration on Cultural Heritage of Malacca, specifically only in Malacca. Those are administered by respective heritage unit in each states; which functions as advisory body pertaining to policy and management on heritage and conservation within the State. This is agreed with statement by Kayan and Zuraini (2004) claimed state or district laws are not concurrent with national policy in building conservation in Malaysia.

Looking closely into both legislative frameworks, accessibility for PwDs within heritage sites is only regulated on Persons with Disabilities Act 2008 but no specific clause is encountered in National Heritage Act 2005. It is believed that the amendment of UBBL in Section 34A bridges both barrier free environment approach and conservation principle (Figure 1). Notwithstanding provision of codes of practices specify only fundamental requirements with basic measurement for new built buildings; but not historical sites with heritage significances. There is lack of guideline to improve accessibility within heritage properties in comparison to developed countries for example United Kingdom, Australia and Singapore (Marsin, Arifin \& Shahiman, 2014). Thus, it came to the research studying on design principle to reconcile both conservation principle and barrier free environment to achieve accessible heritage sites for PwDs.
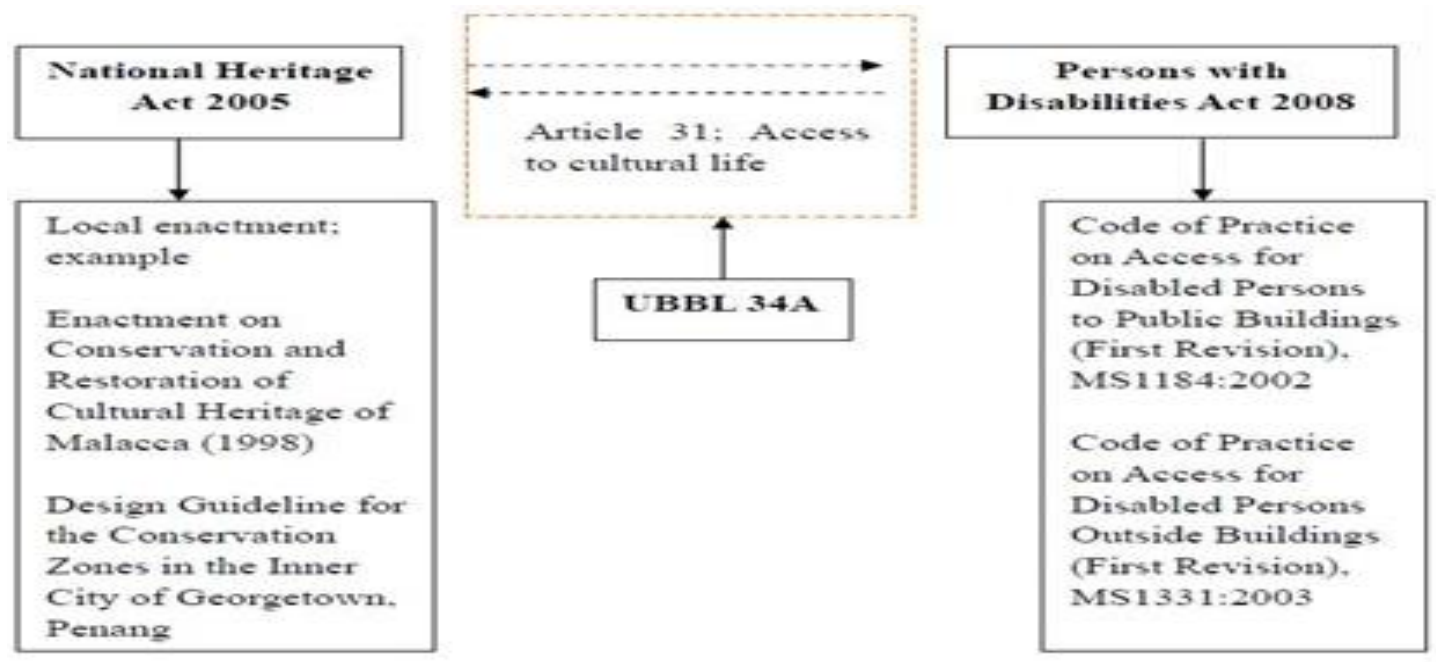

Fig. 1: Correlation of National Heritage Act and Persons with Disabilities Act in Malaysia 
Unlike conservation practice in England, English Heritage has drafted a comprehensive guidance consists introductory of heritage act to potential adjustment in making accessible heritage. The Code of Practice on Accessible Heritage Sites has been adopted as the imperative means of consensus between disability and heritage act in England. Part M of Building Regulation in 2000 contains the specific details to deal primarily with resolution to physical access issues pose to historic site and building.

\section{DEFINITIONS AND PERCEPTION OF ACCESSIBLE HERITAGE}

Since the research topic - accessible heritage is a new paradigm and phenomenon on-going research area; its definition has yet well defined. However, the international congress in tourism sector has promoted the idea of accessible tourism and induces the practice in this industry. Conferences, recognitions and declaration have been put forward as impetus to upsurge the practice in globe. Thus accessible tourism could be the model to exemplify solution for accessible heritage.

'Accessible tourism' is a form of tourism that involves collaborative strategically planned process between stakeholders that enable people with access requirements to function independently and with equality and dignity through universal designed products, services and environments (Darcy, 2010: Darcy \& Dickson, 2009). The definition was developed by $\operatorname{Darcy}(2010)$ after understanding from series of research papers where it was inspired from theoretical areas of disability studies (Gleeson,
1999: Oliver, 1996), leisure constraints (Daniel, Rodger \& Wiggins, 2005; Jackson \& Scott, 1999), tourism systems (Leiper, 2003: Leiper, Stear, Hing \& Firth, 2008) and human right approaches (Darcy \& Taylor, 2009: United Nations, 2006). This concept is parallel to international and regional conventions, in particular the BMF for Action towards an 'Inclusive, Barrier-free and Right based Society' in Asia and Pacific (UNESCAP, 2002). According to UNESCAP, eliminating physical obstacles and social barriers can build accessible environment for all. The barrier free environment weights against efficiency and comfort ability of users rather than appearance of assistive devices or physical access. It aligns with concept of Takayama Declaration which promoting accessible tourism entails removal of attitudinal and institutional barriers in society, and encompasses accessibility in physical environment (ENAT, 2009). In such this concept is employed in this research paper which centered accessibility for PwDs within heritage site that are publicly accessed by all.

There are different disabling barriers impinge on different ways and generate vary responses from broader cultural and social milieu. All these differences have salient impacts to practicing and particular needs are specifically required. Referring to Table 3 statistic on categories of disabilities registered in Malaysia, physical disability has been the highest number of increasing PwDs from year of 2010 to 2014. Let it temporary difficulties or permenantly disability for example wheelchair user, physical disability is the most prevailing in society. Moreover physical disability reflects the most basic easy access to meet barrier free environment.

Table 3: Categories of PWD registered in April 2014

\begin{tabular}{|l|c|c|}
\hline \multicolumn{1}{|c|}{ Categories of disability } & 2014 (As of April) & 2010 (As of August) \\
\hline Learning Disability & 182,055 & 120,414 \\
\hline Physical Disability & 166,206 & 108,952 \\
\hline Hearing Disability & 59,868 & 39,814 \\
\hline Sensory & - & 27,821 \\
\hline Mental & 21,237 & 3,295 \\
\hline Speech Disability & 3,792 & 249 \\
\hline Visual & 47,712 & - \\
\hline Multiple Disability & 25,349 & 13,140 \\
\hline Others & - & $\mathbf{3 1 3 , 6 8 5}$ \\
\hline TOTAL & $\mathbf{5 0 6 , 2 2 8}$ & \\
\hline
\end{tabular}

(Source: Department of PWD, DSWM) 


\section{ACCESSIBLE HERITAGE DESIGN PRINCIPLE}

Conservation and barrier free environment were two different approaches in olden days had yet accessible heritage been inaugurated. Both approaches were governed under respective design principles and regulations to accomplishment. However dealing with building heritage, conservation guidelines are centered in the practice. Yet accessible heritage is still under-researched phenomenon and a new inception especially in the Asia Pacific region. Till inauguration of accessible tourism and developed country has well established with a guidance framework to achieve barrier free heritage environment.

Conservation practice has been developed since adoption of the Venice Charter which first defined historic monument embraces from single architectural work to urban or rural setting that acquired cultural significance with the passing of time (Venice Charter, 1964). Scope of heritage has been even further continued to expand inclusion of inherited heritage value which forms intangible part of its historical resources. The concept evolves to underline 'cultural significance' or synonyms with heritage significance and cultural heritage value in Burra Charter; disseminates maintaining the origin of property and replacement as central of conservation philosophy. 'Authenticity' and 'integrity' have turn into primary objective and requisite of conservation practice in globe. Indeed they are included as inscription assessment criteria for the World Heritage Convention and other cultural inventories. Moving further, Nara Document and the latest Hoi An Protocol had been formulated to give practical operational guideline for conservation practitioners specifically in Asia Pacific; thereby high standard of best conservation on authenticity practice was established for Asia and Pacific region.

To further extend, conservation approach came to inclusion of barrier free environment approach since inception of accessible tourism. The accessible heritage became new paradigm of built heritage in Asia Pacific region, not to mention Malaysia. Nevertheless, previous researches encountered standard sets of guideline are irrelevant for all heritage sites. It was supported by Martin (1999) claimed that some heritage buildings may only permit to certain degree of independence; due to each heritage building has its very nature posses unique limitations and opportunities. Heritage significance varies in unique tangible and intangible heritage value to each building or site. In addition, the major aggregating of barriers in heritage building context due to their functional and presentational impacts differs to individual and social implications. Conflicts often happen to balance parenthesis between both conservation and barrier free environment approach.

There is impossible to provide access to every part of the heritage buildings or sites due to preservation of historical significance. Architectural modification and innovative management approaches is the one solution to preserve the visual and historical integrity in accommodating accessibility for persons with disabilities.

(Prudon \& Dalton, 1981)

The statement clarified it is difficult to make the entire existing or heritage properties accessible for PwDs; due to some heritage sites may only permit to certain degree of independence. Hence amendment or alteration to historical properties is restrained from its heritage significance. Standard design guidelines are not always applicable to all, but a policy of providing dignified and easy access is desired (English Heritage, 2004).

English Heritage has been the forerunner set out a comprehensive top-down system where the process of accommodating easy access into heritage sites is regulated under standard practice and comprehensive framework. Instead of standard regulation, an access planning incorporating access strategy and conservation assessment are undertaken in achieving accessible heritage. Firstly, conservation assessment is another essential procedure to review historical significance of heritage properties before concluding the access planning. Indeed access auditing is positioned as initial assessment before concluding the access planning for heritage properties undertaken. It is strongly emphasized by Kent (2004) who claimed access auditing is the preliminary assessment to examine heritage properties as the first step to establish access planning. There are steps and general approaches to examine to what extend the heritage property are presently accessible initiated by Prudon \& Dalton (1981) and Martin (1999).

It identifies barriers and determines access provision into heritage properties (English Heritage, 2004). Subsequently, the access planning will be examined with local 
conservation guidelines and approaches to justify feasibility and appropriateness without diminishing its unique heritage significance from case to case basis. Principally the new insertion or modification should be not adversely affected its heritage significance and reversible in anytime when it is not required. However arguments have been existent due to new insertion should be treated distinguishable from its fabric or imitates past style to blend into its original context. These were argued by Chapman (2007) in two different approaches to preserve its cultural significance offering an authentic experience while conform to current statutory requirements. Martin (1999) pointed out additional new access features to heritage buildings also reflects changing of attitude towards accommodating easy access to needs of PwDs; it evidences today's social attitudes to future generations towards building heritage. As long it respects to their context and special regards counted; such as scale, height, form, massing, the traditional pattern of frontages, vertical and horizontal emphasis and detailed design (Balderstone, 2007). The final result should be visually compatible with existing fabric which has been interpreted by Martin (1999) in the means of sympathetic alteration. It is parallel to philosophy of Burra Charter, stated in Artile 22, reads;

'New work such as additions to the place may be acceptable where it does not distort or obscure the cultural significance of the place, or detract from its interpretation and appreciation. New work may be sympathetic if its sitting, bulk, form scale, character, colour texture and material are similar to the existing fabric, but imitation should be avoided."

(Burra Charter, 2013)

\subsection{REASONABLE ACCOMMODATION}

Reviewing back to the Persons with Disability Act 2008 in Malaysia, 'Reasonable Accommodation' is cited to inform appropriate modifications and adjustment not imposing a disproportionate or undue burden where needed in a particular case (Persons with Disabilities Act, 2008). It adopts the definition from CRPD;

'Reasonable accommodation' means necessary and appropriate modification and adjustment not imposing a disproportionate or undue burden, where needed in a particular case, to ensure to persons with disabilities the enjoyment or exercise on an equal basis with others of all human rights and fundamental freedom.
By removing barriers appropriate modification or adjustment without effect the original fabric is the essence of the practice in achieving barrier free environment in reference to the statement. It even allows assistive devices provided it will not cause to undue burden and cost effective to the proposed sites or buildings. Importantly, the barriers ought to be well recognized in the context which has been defined in Takayama Declaration;

"Barrier-free refers to a situation where physical, information, institutional and attitudinal barriers for a particular group of people (i.e., persons with disabilities, older persons) are removed so that they may fully participate in society on an equal basis with others;"

(ENAT, 2009)

In fact it is parallel with model of disability concept recognized by the Persons with Disability Act 2008; 'attitudinal barriers' and 'environmental barriers' are asserted as obstacles hinder their full participation. Literally barrier free environment weights against efficiency and comfort ability of users rather than appearance of assistive devices or physical access. It is supported with statement by Yaacob (2009) in an interview; 'barrier-free' would be the idea resultant to inclusion of disability issues into social development and evolves concept of interaction between PwDs with the environment and attitudinal barriers.

Alike practicing in developed country such as England, Code of Practice on Accessible Heritage Sites quotes 'reasonable adjustment' while Part $\mathrm{M}$ of the Building Regulation in England requires 'reasonable provision', the interpretation takes the same parameter except the terminology. This clearly evidences that it is the fundamental gauge to weigh balance between both contradicting approaches. Ultimately reasonable adjustment or alteration is allowable within its parameter as far as the targeted groups practice equally and independently without discrimination (CRPD, 2006). Alteration to remove physical barriers could be achievable within the parameter as long heritage values are well preserved. Significantly, barrier free environmental principle is compatible in accommodating accessibility needs for PwDs in heritage properties. Apparently it is the key word as agglutinate agent to reconcile both barrier free environment approach and conservation principle. 


\section{ACCESS AUDITING TO HERITAGE SITE}

As discussed before, it is impossible to make entire heritage site accessible due to its unique heritage significance. Thus access strategy is important to justify the access routes and accessible points for PwDs within heritage sites (English Heritage, 2004). It is an alternative ways to ease the barriers are possible in heritage sites; as suggested by the Code of Practice on Accessible Heritage Property;

Accessibility can be facilitated by adopting a proactive and consultative approach to design and deliver service that does not compromise either the archeological, historical or environmental characteristics of heritage properties.

(National Disability Authority, 2011)

Prior to the access planning strategy, English Heritage (2004), Prudon \& Dalton (1981), (Martin, 1999), Kent (2004), and (Yaacob \& Hashim, 2005) agreed that access auditing should be the fundamental exercise to carry out at the first place. It is the preliminary assessment to identify critical provision and; to examine heritage property as the first step to establish access planning (Kent, 2004). Martin (1999) also emphasized access auditing as a tool to determine existing and required level of accessibility. It evaluates access options within a conservation context. Access audit practice has been initiated in due course of the Disability Discrimination Act 1995 in England; and adopted in Asia and Pacific region in carrying out access planning either new or old buildings. Eventually it becomes a necessary tool to dissolve access barriers.

On top of access auditing, conservation assessment should be conducted to the heritage properties at the same time. The assessment is important to reveal its unique heritage significance of each case and record alteration or amendment on the latest conservation. Conservation assessment is crucial to identify the critical elements which should be preserved authentically and integrity to the site. Since uniformed guideline is not sensible for all heritage sites, Burra Charter, Hoi An Protocol and Nara Documentation on Authenticity are the references for region; besides local heritage guidelines as mentioned before.

The access audit is driven by a checklist which includes all building component in indicative with basic anthropometric standard to measure appropriateness of the easy access provisions and in reference to local regulations and guidelines. In this research study, the checklist employed the Access Audit for Existing Building Checklist which was created in accordance to Malaysian Standards with reference to barrier-free approach embracing safety, usability and accessibility by Yaacob \& Hashim (2005). The barrier free environment approach was adopted into the checklist because it is the main approach drive to Inclusive Heritage Tourism (Yaacob, 2007). The checklist has been employed to existing and new built buildings in Malaysia; significantly on heritage buildings as case studies undertaken by Yaacob \& Hashim (2008) researched on 'Using Access Audit to Achieve Sustainable Viability of Heritage Properties'. However, Phan (2009) encountered the existing checklist is deficiency to audit heritage properties in Malaysia since conservation aspects has not been captured in the assessment where heritage significance was not considered in the checklist. The encountered accessibility problems mainly focus on the building elements but accessibility route and determination of access point were not audited. Sequence of the journey within heritage sites was not considered in the checklist.

Eventually, the access auditing only managed to measure accessibility problems based on the basic standard rather integral accessibility system within heritage sites. In such, preliminary study in the research initiated another inventory - Access Audit Inventory for Heritage, to assist the existing access audit checklist aligned with core elements of access points in heritage buildings. It classified the auditing items and laid out journey of visiting to the heritage properties orderly as shown in Table 4. According to English Heritage (2004), access auditing should be carried out following sequence of journey from approaching by public or private transport, entry into the site, access to each of the services until finally exit route and leaving the sites at the end of visit. Generally, the ideal easy access to heritage site or building should start from previsiting information, approach and entry to the place until end of visiting. It can refer to the nine core elements as stated in the Code of Practice on Accessible heritage Sites (NDA, 2011) and the Accessible Historic Environment: Supplementary Planning Document (Artherton, 2004). The core elements consist of external and internal building components and service provisions along the journey of visiting. Factors such as surface texture, widths, gradients, steps, weight of doors, restriction of access, signage, 
clarity of interpretive material and audiovisual presentation must be considered (Martin, 1999).

Phan (2009) revealed twelve buildings elements are the common accessible problems within heritage buildings in Malaysia; especially approach and entry, accessible toilets and ramps. The building elements were concluded in an inventory list in reference to the core elements and accessible path approach as literally reviewed from NDA (2011), Artherton (2004),English Heritage (2004), Martin (1999) and Prudon \& Dalton (1981). Besides, the inventory includes secondary services which are effective tool as mobility aid, supportive services and facilities to users. In consideration of alternative way to address barriers which are unable to be physically removed and assistive devices could be segregated structure or additive physical access features to overcome the obstacles.

Table 4: Core elements of accessible provisions in heritage sites

\begin{tabular}{|c|c|c|}
\hline Core Elements & $\begin{array}{c}\text { Access Audit Inventory for } \\
\text { Heritage }\end{array}$ & $\begin{array}{c}\text { Access Audit Form for Existing } \\
\text { Building }\end{array}$ \\
\hline Pre-visit Information & Service Provisions & - \\
\hline \multirow[t]{2}{*}{ Accessible Parking } & \multirow[t]{2}{*}{ Parking } & Item 2: Car Parking \\
\hline & & Item 3: Passenger Loading Zone \\
\hline \multirow[t]{2}{*}{ Approach \& Entry } & \multirow[t]{2}{*}{ Approach \& Entry } & Item 1: Accessible Footpath \\
\hline & & Item 20: Taxi Stand / Bus Stop \\
\hline Entrance & Entrance & Item 4: Entrances and Doors \\
\hline Lift & Lifts & Item 15: Lifts \\
\hline \multirow{5}{*}{$\begin{array}{l}\text { Accessible Toilet / } \\
\text { Accessible Bath }\end{array}$} & \multirow[t]{5}{*}{ Accessible Toilet } & Item 6: Public Toilet \\
\hline & & Item 7: Accessible Toilet \\
\hline & & Item 8: Accessible Shower \\
\hline & & Item 9: Accessible Bath \\
\hline & & Item 10: Urinals \\
\hline Emergency Exists & Emergency Exits & Item 11: Emergency Egress \\
\hline \multirow[t]{2}{*}{ Ramp } & \multirow[t]{2}{*}{ Ramps } & Item 12: Step Ramp \\
\hline & & Item 13: Ramps \\
\hline \multirow[t]{7}{*}{ Accessible Path } & \multirow[t]{2}{*}{ Stairs } & Item 14: Stairs \\
\hline & & Item 16: Escalators \\
\hline & Doors & Item 4: Entrances and Doors \\
\hline & Wayfinding / signages & Iten 17: Wayfinding and Signs \\
\hline & \multirow[t]{3}{*}{ Accessible floors } & Item 5: Rooms \& Areas \\
\hline & & Item 18: Public Telephones \\
\hline & & Item 19: Accessible Hotel Bedroom \\
\hline
\end{tabular}

\section{FINDING AND DISCUSSION}

Table 5 indicates core elements encountered in the case studies which conform to the accessibility needs as spell out in the checklist. The table was summarizes from each access auditing report, illustrates presence provision of accessibility needs for PwDs since the restoration. However, not all core elements were attended in all three case studies. Out of nine core elements as listed, approach and entry, ramp and accessible toilet are considerably accessible for physical challenged users. Although not completely well addressed, the basis of accessibility is resolved. Nevertheless, the provision seems to be had-hoc and not integrated within conservation planning process. Open interview with managing officer or Leong San Tong Khoo Kongsi and St. Geroge Church, both restoration projects were planned without access planning process at the initial stage. The provision was performed in view of good practice by the managing team after the restoration in order to include PwDs visitors. Except Suffolk House which started the restoration with inclusion of barrier free approach in the planning, as claimed by the managing officer of Suffolk House. This concluded that the remnants of provision in conservation practice likely due to the consultant 
team who eliminates accessibility for physical challenged users in their professional practice. Perhaps barrier free approach is challenging to fit in the restoration plan due to restriction of conservation statutory and guidelines. Moreover, constitution has yet put forward any mandatory and guidance to accomplishment.
Despite the concept of barrier free environment approach was adopted in the case studies, appropriateness of provision has yet well resolved. Looking closely into each of the core elements, there is still deficiency in practice which is sub-standard and superficial resolution on site.

Table 5: Core elements of accessible provision in case studies

\begin{tabular}{|c|c|c|}
\hline Case Study & Access Features & Core Elements \\
\hline \multirow[t]{4}{*}{$\begin{array}{l}\text { Leong San } \\
\text { Tong Khoo } \\
\text { Kongsi }\end{array}$} & $\begin{array}{l}\text { Website provides basic information with photo gallery, } \\
\text { history and layout drawings of the site. } \\
\text { A virtual tour has been developed into CD to show around the } \\
\text { building }\end{array}$ & Pre-visit information \\
\hline & $\begin{array}{l}\text { An accessible toilet is provided in adjacent building. The } \\
\text { toilet complies with basic standard. }\end{array}$ & Accessible Toilet \\
\hline & \multirow{2}{*}{$\begin{array}{l}\text { A structure concrete ramp is located at the entrance to } \\
\text { accessible toilet; and a reversible timber ramp is provided at } \\
\text { the entrance to museum at the basement level. }\end{array}$} & Ramp \\
\hline & & Approach \& Entry \\
\hline \multirow{4}{*}{$\begin{array}{l}\text { St. George } \\
\text { Church }\end{array}$} & \multirow{3}{*}{$\begin{array}{l}\text { A reversible metal ramp is located at alternative entrance for } \\
\text { persons with access needs. }\end{array}$} & Ramp \\
\hline & & Approach \& Entry \\
\hline & & Entrance \\
\hline & $\begin{array}{l}\text { Accessible parking bays are located near to the ramp. The size } \\
\text { complies with the standard. }\end{array}$ & Accessible Parking \\
\hline \multirow[t]{7}{*}{ Suffolk House } & $\begin{array}{l}\text { Concrete pavement is provided at aside to ease the loose } \\
\text { gravel pathway. It connects to a timber ramp leading to the } \\
\text { main entrance and is continued with a brick pavement to the } \\
\text { ancillary building behind the main building. }\end{array}$ & Approach \& Entry \\
\hline & \multirow{2}{*}{$\begin{array}{l}\text { A reversible timber ramp is provided at the main entrance. } \\
\text { The timber main door is kept opening during operation. }\end{array}$} & Ramp \\
\hline & & Entrance \\
\hline & \multirow{2}{*}{$\begin{array}{l}\text { An accessible footpath is mapped out starting from entrance } \\
\text { gateway to additional lift to first floor level at the annex block. }\end{array}$} & Accessible Path \\
\hline & & Lift \\
\hline & $\begin{array}{l}\text { An accessible toilet is provided in the annex block. It fully } \\
\text { complies with the standard. }\end{array}$ & Accessible Toilet \\
\hline & $\begin{array}{l}\text { Emergency exits for the first floor level is connected to the } \\
\text { fire escape stair at the annex block. }\end{array}$ & Emergency Exits \\
\hline
\end{tabular}

\subsection{APPROACH AND ENTRY}

Access auditing in each case study reported the entrance has addressed the need of accessibility for physical challenged users. Road access with non-slippery and firm finishing has been provided along the drive way from ingress of the site boundary towards main entrance of the building. However, safety for the users is an issue because there has no demarcated pathway for pedestrians along the access and exposed them to vehicle traffic, especially St. George Church. Approaching from the St. George Church's gateway towards the entrance porch; pedestrians are only able to walk on the tarmac driveway which leading to the compounded car parking space.

On the other hand, Leong San Tong Khoo Kongsi and Suffolk House have different site planning in comparison to St. George Church. Pedestrians are relatively safe to walk along the pathway from their gateway since vehicles are restricted within the compound except with occasionally permission from Khoo Kongsi and Suffolk House. Both site compounds have been gated from public access for security reason and ticketing collecting. Pedestrian pavement is clearly designated segregation from vehicle traffic. 
Khoo kongsi is finished with granite pavement but uneven surface and big joining gaps might trap wheelchair users and clutches users. Creditably to alley is wide enough for trishaw or car drive through to drop off visitors with permission into the compound. While Suffolk House has well demarcated pedestrian walkway from vehicle driveway access although the vehicle is only allowed with permission to drive in.

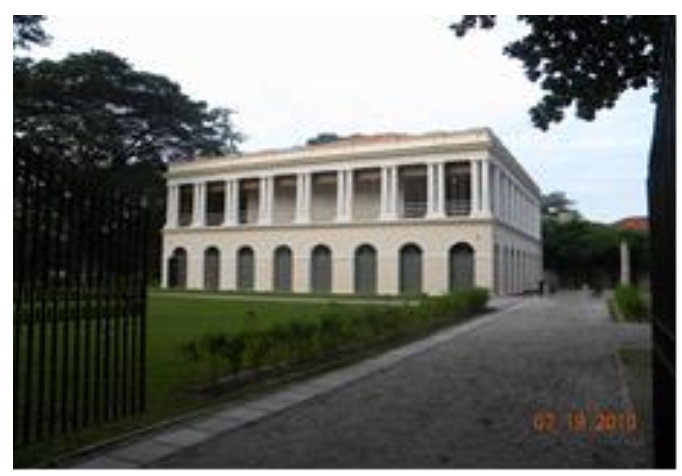

Fig. 2: Concrete pavement demarcates the accessible footpath

\subsection{RAMP}

In these three case studies, there are ramps being designed for easy access of wheelchair users. Different materials are used to counter the original fabric of the heritage buildings in order to fit authenticity and integrity in conservation practice. They are light and reversible structures without burden to origin of the fabric. Nevertheless, study encountered gradient of the ramps are vary; possibility due to space constraint to allow for sufficient span distance.

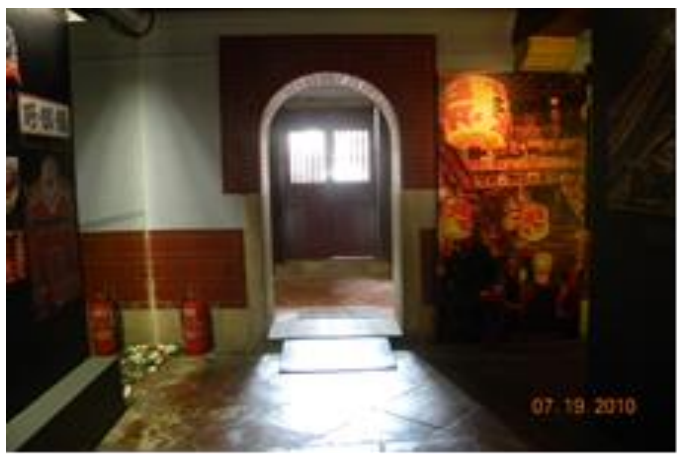

Fig. 4: Timber and metal ramp at the entrance to Khoo Kongsi Museum
Suffolk House exemplify footpath network connecting gateway to main entrance with fair case brick pavement and timber ramp leading from main entrance to the annex block behind the main building. The pathway has preferably mapped out and designated a clear footpath to visitors during the restoration. Hence, design is well incorporated with the main building and complement to the landscape of surrounding setting.

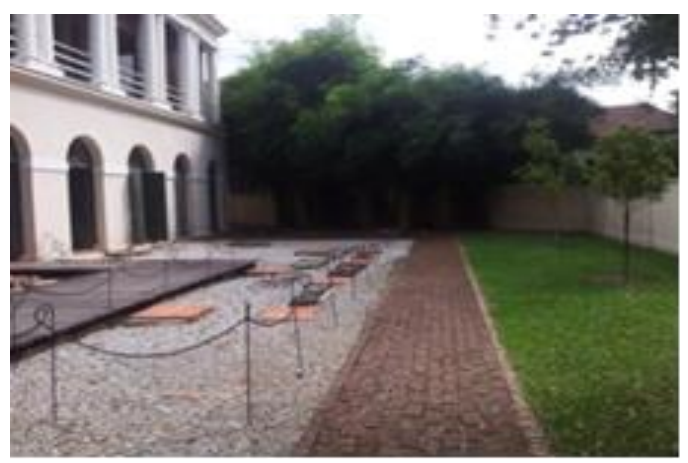

Fig. 3: Fair face brick pavement connects timber ramp to ancillary block at back yard

There are temporary timber ramp at the entrance and portable metal step ramps at threshold of door ways at the ground floor museum area (Figure 4 \& Figure 5). The step ramps are constructed with gradient in rang 1:2 to $1: 5$ which is too steep for wheelchair users. Moreover the portable ramps are not sturdy fixed to floor and are hazardous to their safety. They are added after restoration as claimed by the managing officer in an interview due to a good practice for them to consider accessibility needs for visitors with physical challenged. Unfortunately the solution still not well executed to ensure its appropriateness.

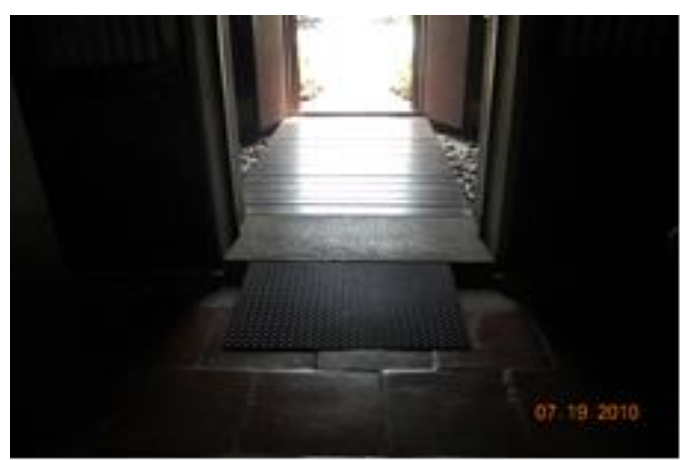

Fig. 5: Portable ramps at threshold of door way in Khoo Kongsi Museum 
St. George Church has been added an alternative entrance with ramp at the side entrance in facing to the open car park area (Figure 6). It was planned in previous restoration in view to cater for visitors with disabilities from an organization who occasionally come for Sunday service. The alternative entrance takes one bay of existing window next to altar shrine of the church. It was designed to ease the four steps at the entrance from ground level with gradient at 1:6. Obviously, it is still steep for wheelchair users to maneuver by themselves and most of the visitors are assisted as claimed by the managing officer during the interview.

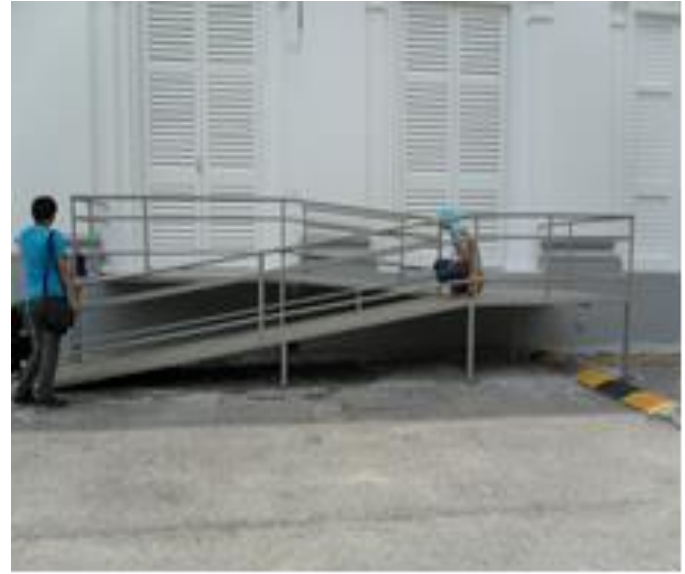

Fig. 6: Additional metal ramp at alterative entrance of St. George Church

Viewing back to the three case studies, the ramps are built against to Malaysia Standards. In reference to the guidelines, the gradient of ramp should reach minimum 1:14 with maximum $10 \mathrm{~m}$ span distance. The standard measures a gentle ramp which could be maneuver by wheelchair users without assistant for all strength. Nevertheless, the gradient is difficult to conform due to insufficient space to accommodate correct span distance. Even not to surprise when consultants and professionals design the ramp negligently and disregard of Malaysian Standard.

\subsection{ACCESSIBLE TOILET}

In most cases of heritage sites, it is a challenge to accommodate an accessible toilet for visitors with PwDs within the original fabric. A major construction will be acquired to fit in all new supporting appliances and technical works without affecting to the original structure. In addition, accessible toilet requires adequately room space especially turning space for wheelchair users. However, according to
Creditably Suffolk House provides a better example in constructing a gentle ramp of timber decking leading to the main entrance (Figure 7). Gradient at 1:10 is apparently an exemplary in accessibility and subtly integrated with the setting of fabric. The metal ramp is sturdy fixed to the timber decking and well enclosed gaps between the loose gravel and timber platform. The ramp was well thought off to locate at the beginning of the timber platform rather finished right at the raised entrance door way. The timber platform gives a seamless floor level entering to the main lobby area.

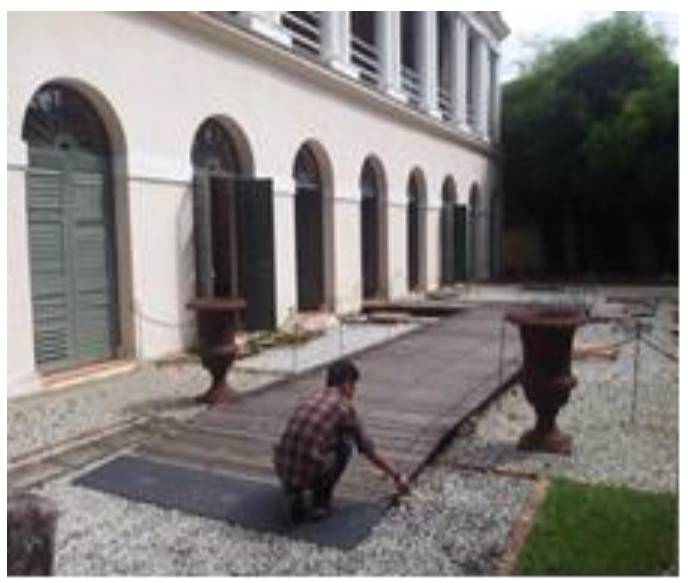

Fig. 7: Metal ramp to timber decking leading to main entrance of Suffolk House

conservation guidelines, minimum intervention is only allowable for highly graded heritage buildings. Hence the construction work would burden to the superstructure.

However, new accessible toilet was sensibly planned in restoration work of Khoo Kongsi and Suffolk House. Both cases initiated the requirement in their design brief during planning process since their managing committee was looking into a complete service for all visitors. Notably both heritage sites are ticketing admission thus complete facility is needed at the first place, particularly accessibility. The accessible toilet is housed in adjacent buildings which detaches from the main buildings of the sites. The toilet was added to the adjacent townhouse from the main house of Khoo Kongsi (Figure 8) and Suffolk House accommodated the toilet in an annex block behind the main house (Figure 9). Without further creates undue burden to the superstructure, the accessible toilet was appropriately planned in the restoration. 


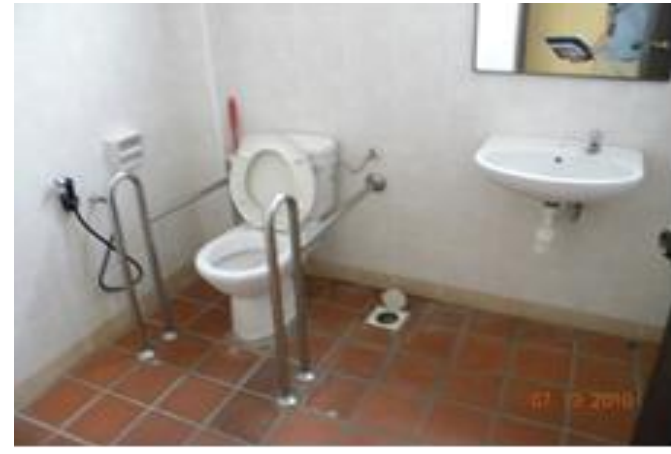

Fig. 8: Accessible toilet at adjacent building of Khoo Kongsi

\subsection{ACCESSIBLE CAR PARKING}

Among three case studies, St. George Church is the only heritage site which provides accessible car parking bays within the compound. It was located near to the alternative entrance with ramp as shown in Figure 10. Even the ratio in one accessible bay over one hundred standard bays is required in Malaysian Standard yet the managing committee still provides in view of good practice. However, the accessible car parking bay has yet appropriately demarcated to conform the standard requirement especially allocating transfer zone. There is also absence of zebra crossing connecting to the alternative entrance to slow down vehicle traffic.

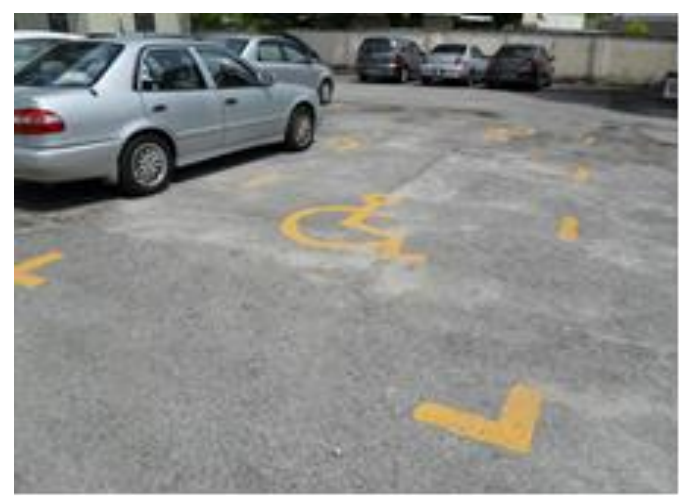

Fig. 10: Accessible parking bay at St. George Church

\section{CONCLUSION}

Reviewing back to the case studies, obviously the fundamental basis in making heritage sites accessible has yet thoroughly comprehended by consultant and professional team. Heritage restoration in current practice is weighed against conservation principle than barrier free environment approach. Despite authenticity and integrity should be centered in conservation practice yet human rights of PwDs is still importance to achieve inclusion society.

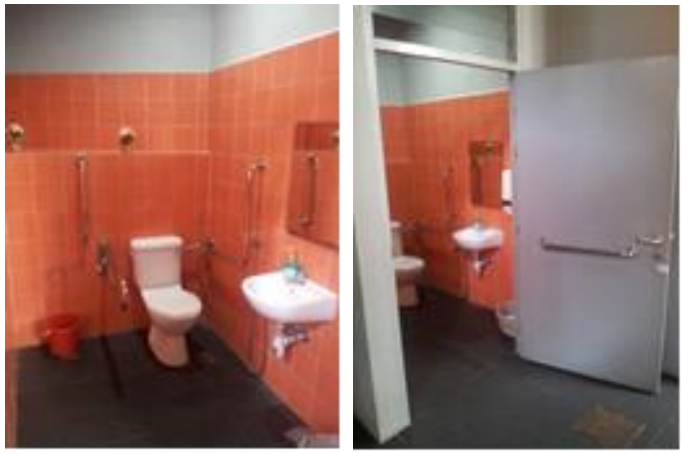

Fig. 9: Accessible toilet at the ancillary building block of Suffolk House

Notwithstanding deficiency in international charter or existing national heritage guidance is recent enough to express accessibility needs of PwDs in heritage sites (Foster, 1997). The study encountered barrier free environment approach likely able to enclave the gaps by 'reasonable accommodation' to certain extend without diminishing heritage value of its fabric.

Thus access auditing should be employed at the first place to justify the access planning in corresponding to conservation assessment simultaneously. As long the fundamental core elements as identified in the research are well planned in the initial stage of conservation planning. The case studies concluded the fundamental core elements in accessible heritage include approach and entry, ramps, accessible toilet and accessible car parking.

Prior to the access planning, it is important to explain clearly that the word 'access' should be interpreted- include access to and within any building or site, access to all facilities and services and to any information (Martin, 1999). According to National Disability Authority (2011) and Prudon \& Dalto (1981), access should be provided to total pathway - from initial approach; to all parts of the building, to services and to information. Accessible routes shall connect from one meeting point to other service provisions where PwDs are able to access independently. The concept of 'accessible path' was developed as a straightforward way to determine if a severely disabled person in wheelchair could travel from one point to another (Prudon \& Dalton, 1981). Instead of making the entire heritage site accessible for PwDs, the provisions shall take place at entry point, decision making and lastly exit point. In short, accessible heritage is not imposed on standard guidelines but a strategy mapping from case to case basis taking into consideration of 
heritage significances and the conduciveness of accessibility needs of physical challenged visitors.

\section{REFERENCES}

Artherton, E., (2004). Accessible historic environment supplementary planning document, Paper to Cotswold District Council

Barrier Free Environments, inc. (1993). UFAS retrofit guide: Accessibility modifications for existing buildings. New York: Van Nostrand Reinhold

Buntan, M. (2011), Accessible Tourism: A strategic example of CRPD implementation. Speech presented at International Conference on Accessible Tourism, Taiwan

Darcy, S. (2006). Setting a research agenda for accessible tourism. Sustainable Tourism CRC.

Disabled People's International Asia Pacific (DPI-AP), (2007). Bangkok recommendation on accessible tourism in Asia and Pacific, International conference on accessible tourism, Thailand: Bangkok, 22-24 November 2008, Bangkok, Thailand: Sawang Srisom, ARDO, retrieved 7 September 2009 from DPI-AP organizations database

English Heritage, (2004) Easy access to historic buildings, English Heritage

Engelhardt, R. A., Unakul, M. H., \& Endrina, E. (Eds.). (2007). Asia Conserved: Lessons learned from the UNESCO Asia-Pacific Heritage Awards for Culture Heritage Conservation (2000-2004).

Economic Planning Unit. (2010). Tenth Malaysia Plan 2011- 2015.Malaysia: Malaysia Government.

ENAT, Retrieved 08.01 .2013 at.www.accessibletourism.org/?i=enat.en.fa q.744.

Engelhardt, R. A. (2010). "First Principles" in Conservation: The UNESCO Asia-Pacific Heritage Awards. APT Bulletin, 41(2/3), 57-65.

Foster, L., (1997) Access to the historic environment: Meeting the needs of disabled people, Donhead

Government of Malaysia. (2007). Application dossier for registration of historic cities of the Straits of Melaka and George Town. Government of Malaysia Printing Office.

Historical Melaka City Council. (2007). Conservation management plan for the Historic City of Melaka 2nd Edition.

Hussein,H., \& Yaacob, N.M. (2012). Development of accessible design in
Malaysia. Procedia-Social and Behavioral Sciences, 68, 121-133.

Hussein, H. \& Yaacob, N.M. (2012). Malaysian perspective on the development of accessible design. Asian Journal of Environmental Behaviour Studies, 3(8), 101-116

Kayan, B., (2012). Building Maintenance in old buildings conservation approach: an overview of related problems. Journal of Design and Built Environment 2(1). Retrieved 3 June 2013, from e-Journal University Malaya database

Kala, N. (2008). Host perception of heritage tourism impact with special reference to the city of Jaipur. South Asian journal of tourism and heritage, 1(1), 65-74.

Kent, R. (2003). Disability access provisions for historic buildings. The building conservation directory 1998.

Law of Malaysia, Act 685, Malaysia: Persons with Disabilities (2008). Percetakan Nasional Malaysia Berhad

Law of Malaysia, Act 645. National Heritage (2005). Percetakan Nasional Malaysia Berhad

Mace, R. L., Hardie, G. J., \& Place, J. P. (1990). Accessible environments: Toward universal design. Center for Accessible Housing, North Carolina State University.

Preiser, W., Visher, J., and White, E. (Eds.), Design interventions: Toward a more human architecture. New York, NY: Van Nostrand Reinhold.

Municipal Council of Penang Island (1989). Guidelines for conservation areas \& heritage buildings, Municipal Council of Penang Island Printing Office.

Martin, E. (2000). Improving access to heritage buildings. Australian Council of National Trusts.

Orbasli, A. (2002). Tourists in historic towns: Urban conservation and heritage management. Taylor \& Francis.

Prudon, T. H., \& Dalton, S. (1981). The accessible path in historic properties.Bulletin of the Association for Preservation Technology, 13(2), 31-39.

Phan, M.H (2009) Accessibility to national heritage buildings: Towards designing for the needs of disabled and elderly people in Malaysia. Paper presented at $2^{\text {nd }}$ UNESCOICCROM Asian Academy for Heritage Management Conference, Macao, 1-3 December 2009.

ICOMOS, A. (2013). The Burra Charter: The Australia ICOMOS charter for places of cultural significance 2013. 
United Nations Economic and Social Council (2002). Participation of persons with disabilities in Pacific Island countries in the context of the Asian and Pacific decade of Disabled Persons, 1993-2002 and beyond. Bangkok

United Nations. (2006). Convention on the Rights of Persons with Disabilities.

Van Horn, L., \& Isola, J. A. (2014). Toward a global history of inclusive travel. Review of Disability Studies: An International Journal, 2(2).

Yaacob, N.M. \& Hashim, N.R. (2010). Malaysia: An overview of policies on accessibility and Universal Design. International Symposium for Promotion of Universal Design Based Environments in Asian Region. Japanese Association for an Inclusive Society (JAIS). Tokyo, 26-27 June 2010

Yaacob, N.M, Hashim, N. R., \& Aman Hashim, A. (2009). Achieving social equity by addressing the needs of disabled people in heritage building conservation in Malaysia. The International Journal of Environmental, Cultural, Economic and Social Sustainability, 5(4), 51-68.

Yaacob, N.M, \& Hashim, N. R. (2007, July). Inclusive Heritage Toursim: A study on the access needs of dsiabled and elderly tourists in Malaysia. In The 3rd Tourism Outlook Conference and Global Event Congress II, Kuala Lumpur (pp. 227-239). 